\title{
Micro-Sized Cold Atmospheric Plasma Source for Brain and Breast Cancer Treatment
}

\author{
Zhitong Chen, ${ }^{a, *}$ Li Lin, ${ }^{a}$ Qinmin Zheng, ${ }^{b}$ Jonathan H. Sherman, ${ }^{c}$ \\ Jerome Canady, ${ }^{d}$ Barry Trink, ${ }^{e}$ \& Michael Keidar ${ }^{a, *}$ \\ aDepartment of Mechanical and Aerospace Engineering, The George Washington University, \\ Washington, DC, USA; 'Department of Civil and Environmental Engineering, The George Wash- \\ ington University, Washington, DC, USA; 'Department of Neurosurgery, The George Washington \\ University, Washington, DC, USA; dJerome Canady Research Institute for Advanced Biological \\ and Technological Sciences, US Medical innovation LLC, Takoma Park, MD, USA; eDepartment \\ of Otolaryngology, School of Medicine, Johns Hopkins University, Baltimore, Maryland, USA \\ *Address all correspondence to: Michael Keidar and Zhitong Chen, Department of Mechanical and Aerospace Engi- \\ neering, The George Washington University, 800 22nd St NW, Washington, DC 20052, USA, E-mail: zhitongchen@, \\ gwu.edu,keidar@gwu.edu
}

\begin{abstract}
Micro-sized cold atmospheric plasma ( $\mu \mathrm{CAP}$ ) has been developed to expand the applications of CAP in cancer therapy. In this paper, $\mu \mathrm{CAP}$ devices with different nozzle lengths were applied to investigate effects on both brain (glioblastoma U87) and breast (MDA-MB-231) cancer cells. Various diagnostic techniques were employed to evaluate the parameters of $\mu \mathrm{CAP}$ devices with different lengths. Parameters included potential distribution, electron density, and optical emission spectroscopy. The generation of short- and long-lived species (such as hydroxyl radical $[\bullet \mathrm{OH}]$, superoxide $\left[\mathrm{O}_{2}^{-}\right]$, hydrogen peroxide $\left[\mathrm{H}_{2} \mathrm{O}_{2}\right]$, and nitrite $\left[\mathrm{NO}_{2}^{-}\right]$) were studied. These data revealed that $\mu \mathrm{CAP}$ treatment with a $20 \mathrm{~mm}$ long tube has a stronger effect than that of the $60 \mathrm{~mm}$ tube because of the synergetic effects of reactive species and free radicals. Reactive species generated by $\mu \mathrm{CAP}$ enhanced tumor cell death that was dose-dependent and nonspecific to tumor cell type.
\end{abstract}

KEY WORDS: reactive species, glioblastoma cancer, cancer therapy

\section{INTRODUCTION}

Cold atmospheric plasma (CAP) has been proposed as a novel therapeutic method for anticancer treatment, which can be applied to living tissues and cells. ${ }^{1,2} \mathrm{CAP}$ is a partially ionized gas that contains charged particles, reactive oxygen and nitrogen species (ROS and RNS), excited atoms, free radicals, UV photons, electric field, and other substances. ${ }^{3,4}$ ROS and RNS, combined or independently, are known to initiate different signaling pathways in cells and to promote oxidative stress. ${ }^{5,6}$ Plasma-induced biological effects include damage to lipids, proteins, and DNA, and apoptosis induced through plasma-generated ROS and RNS. ${ }^{7-10}$ Moreover, many studies have reported both in vivo and in vitro that plasma is a possible adjunct treatment in oncology. It can kill several cancer cell types, such as glioblastoma, breast cancer, bladder carcinoma, cervical carcinoma, skin carcinoma, pancreatic carcinoma, lung carcinoma, colon carcinoma, gastric carcinoma, melanoma, and hepatocellular carcinoma. ${ }^{11-27}$ 
In plasma medicine, jet plasma, corona discharge, and dielectric barrier discharge (DBD) have been used. ${ }^{28}$ These types of plasma can be directly applied to skin cancers; however, they are not suitable for systemic cancer treatment. Some studies investigated the use of micro-sized plasma devices in live animals. ${ }^{29}$ However, their devices were only used on xenograft tumors and not systemic cancers. Moreover, delivery of the plasma species is crucial to suppress tumor growth and assess efficiency of micro-sized plasma devices. Hence, this study aims to design micro-sized cold atmospheric plasma devices with different nozzle lengths to enhance delivery of reactive species and evaluate the efficiency of these devices for cancer therapy. Figure 1 shows the potential applications of $\mu \mathrm{CAP}$ for brain and breast tumors in the future.

\section{MATERIALS AND METHODS}

Figure 2 depicts the schematic of the experimental setup, including high voltage power (see Fig. 2a) and $\mu$ CAP devices (Fig. 2b). The high voltage power includes DC input, trigger signal and metal-oxide-semiconductor field-effect transistor (MOFSET), and the secondary output. In this work, the DC input was set at $5 \mathrm{~V}$, a square wave signal was obtained from the control unit (see Fig. 2a, upper left), and a high voltage wave was obtained from the square wave signal through the transformer (see Fig. 2a, upper right). The $\mu$ CAP devices consist of a two-electrode (copper) assembly with a central powered electrode (1 $\mathrm{mm}$ in diameter) and a grounded outer electrode wrapped around the outside of a quartz tube $(10 \mathrm{~mm})$, as shown in Fig. $2 \mathrm{~b}$. The electrodes were connected to the secondary output of the high voltage transformer. The peak-to-peak voltage was approximately $8 \mathrm{kV}$, and the frequency of the discharge was around $16 \mathrm{kHz}$ (see Fig. $2 \mathrm{a}$, upper right). The secondary output of the high voltage transformer was connected to

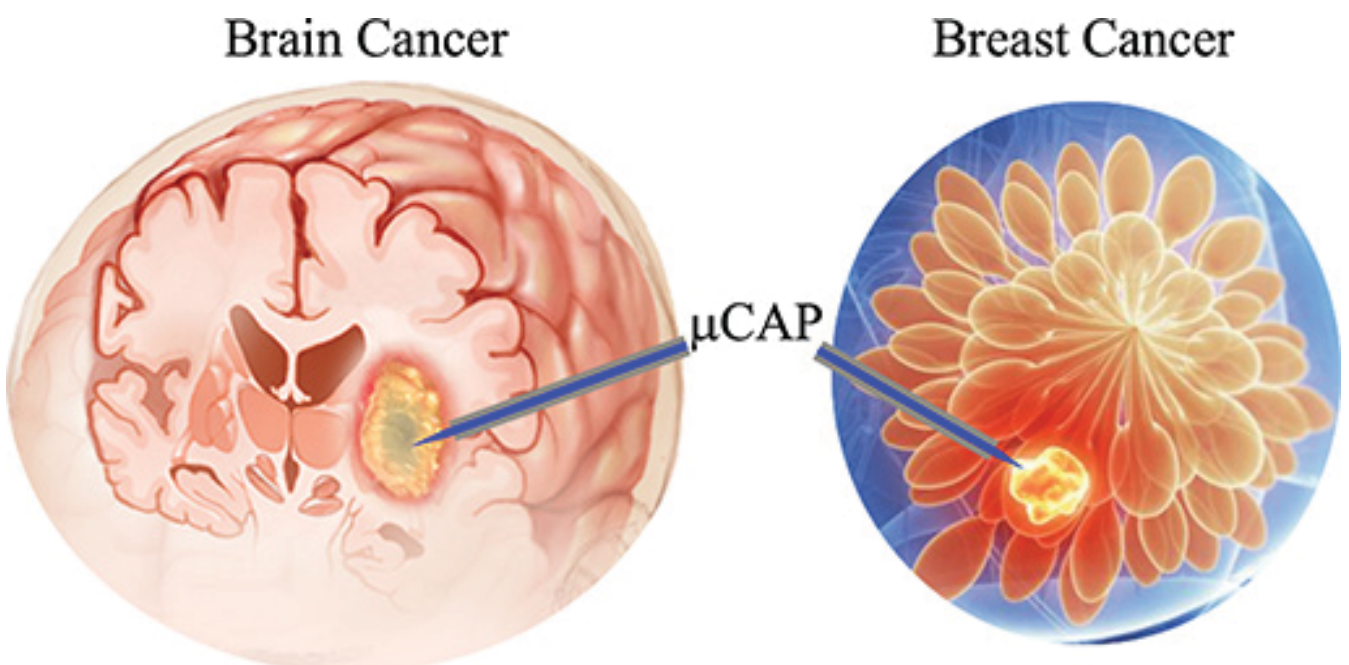

FIG. 1: Potential applications of $\mu \mathrm{CAP}$ for brain and breast tumors 


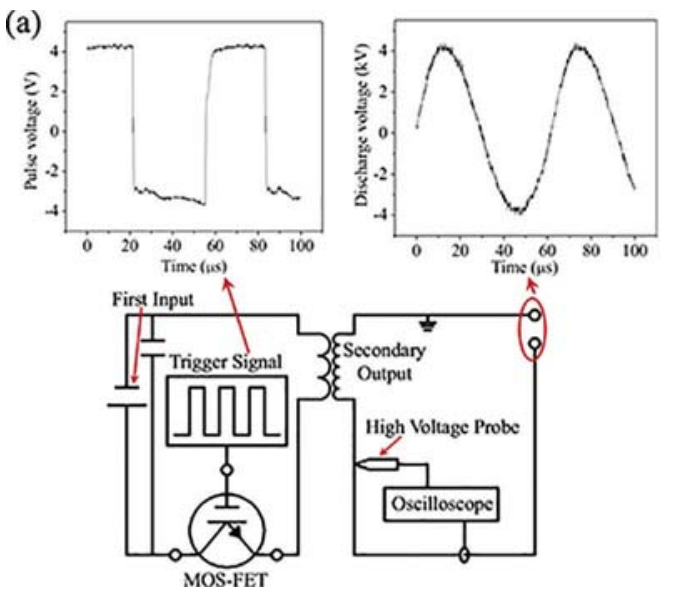

(b)

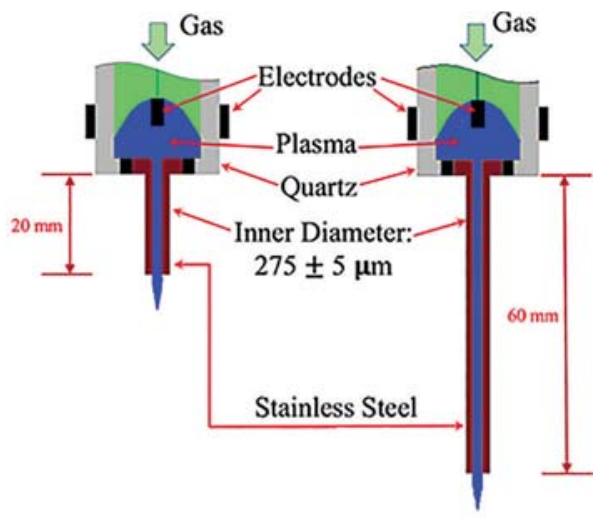

FIG. 2: Schematic representation of the experiment setup including high voltage power part (a) and the micro-sized cold atmospheric plasma with stainless steel tubes that were $20 \mathrm{~mm}$ and 60 $\mathrm{mm}$ long (b)

the first input. At the end of a quartz tube, a capillary tube (stainless steel) with an inner diameter of $275 \pm 5 \mu \mathrm{m}$ and a length of 20 or $60 \mathrm{~mm}$ was attached and insulated with epoxy. The feed gas for this study was industrial purity helium, which was injected into the quartz tube with a $0.2 \mathrm{~L} / \mathrm{min}$ gas flow rate. A longer tube $(60 \mathrm{~mm})$ is needed to access deeper tumors in the brain and breast.

In this study, we are assessing the effect of tube length to understand the limitations of depth. For instance, it is believed that a longer tube $(60 \mathrm{~mm})$ is needed to access deeper tumors in the brain and breast. UV-visible-NIR, a range of wavelengths from 200 to $850 \mathrm{~nm}$, was investigated on plasma to detect various RNS and ROS (nitrogen $\left[\mathrm{N}_{2}\right]$, nitric oxide $[-\mathrm{NO}]$, nitrogen cation $\left[\mathrm{N}^{+2}\right]$, atomic oxygen $[\mathrm{O}]$, and hydroxyl radicals $[-\mathrm{OH}]$ ). The optical probe was placed $1.0 \mathrm{~cm}$ in front of the plasma jet nozzle. Data were then collected with an integration time of $100 \mathrm{msec}$.

A fluorimetric hydrogen peroxide assay kit (Sigma-Aldrich) was used for measuring the amount of $\mathrm{H}_{2} \mathrm{O}_{2}$, according to the manufacturer's protocol. Briefly, $50 \mu \mathrm{L}$ of standard curve, control, and experimental samples were added to 96-well flat-bottom black plates, and then $50 \mu \mathrm{L}$ of Master Mix was added to each well. The plates were incubated for $20 \mathrm{~min}$ at room temperature, protected from light, and fluorescence was measured with a Synergy H1 Hybrid Multi-Mode Microplate Reader at Excitation/Emission (Ex/Em): 540/590 nm.

RNS levels were determined with a Griess Reagent System (Promega Corporation) according to the instructions provided by the manufacturer. Briefly, $50 \mu \mathrm{L}$ of sample and $50 \mu \mathrm{L}$ of the provided sulfanilamide solution were added to $96-$ well flat-bottom plates and incubated for 5 to $10 \mathrm{~min}$ at room temperature. Subsequently, $50 \mu \mathrm{L}$ of the NED solution was added to each well and incubated at room temperature for 5 to 10 minutes. The absorbance was measured at $540 \mathrm{~nm}$ with the Synergy H1 Hybrid Multi-Mode Microplate Reader.

Volume 8, Issue 2, 2018 
XTT sodium salt (2,3-bis(2-methoxy-4-nitro-5-sulfophenyl)-5-[(phenylamino) carbonyl]-inner salt-2H-tetrazolium, monosodium salt) solution, purchased from Cayman Chemical, was prepared by dissolving XTT power in Dulbecco's Modified Eagle Medium (DMEM, Life Technologies). XTT sodium salt solution (100 $\mu \mathrm{L}$ per well, 500 $\mu \mathrm{M})$ in a 96-well flat-bottom plate by $\mu \mathrm{CAP}$ for $5,10,30,60$, and 120 seconds. The gap between the outlet of the $\mu \mathrm{CAP}$ and the surface of the samples was set at approximately $3 \mathrm{~mm}$. As a control, untreated XTT sodium salt solution in triplicate were transferred to a 96-well flat-bottom plate. As a control, DMEM $(100 \mu \mathrm{L}$ per well) was treated with $\mu \mathrm{CAP}$ for $5,10,30,60$, or 120 seconds. The color change of XTT solution was used to indicate the presence of superoxide $\left(\mathrm{O}_{2}^{-}\right)$. A color change of XTT solution was measured with a Hach DR 6000 UV-VIS spectrophotometer at $470 \mathrm{~nm}$.

A methylene blue (MB) solution was prepared by dissolving MB powder in DMEM. MB solutions $(100 \mu \mathrm{L}$ per well, $0.01 \mathrm{~g} / \mathrm{L})$ in a 96 -well flat-bottom plate were treated by $\mu \mathrm{CAP}$ for $5,10,30,60$, or 120 seconds. The gap between the outlet of the $\mu \mathrm{CAP}$ and the surface of the samples was approximately $3 \mathrm{~mm}$. As a control, untreated MB solutions in triplicate were transferred to a 96-well flat-bottom plate. The color change of methylene blue shows the presence of $\mathrm{OH}$ radicals via immediate and distinct bleaching of methylene blue dye (qualitatively analysis). The color change of the MB solution was measured at the absorbance at $664 \mathrm{~nm}$ by a Synergy H1 Hybrid Multi-Mode Microplate Reader.

Human glioblastoma cancer cells (U87MG, Perkin Elmer) were cultured in DMEM (Life Technologies) supplemented with 10\% (v/v) fetal bovine serum (Atlantic Biologicals) and $1 \%(\mathrm{v} / \mathrm{v})$ penicillin and streptomycin (Life Technologies). Cultures were maintained at $37^{\circ} \mathrm{C}$ in a humidified incubator containing $5 \%(\mathrm{v} / \mathrm{v}) \mathrm{CO}_{2}$. The human breast cancer cell line (MDA-MB-231) was cultured in DMEM supplemented with $10 \%$ (v/v) fetal bovine serum (Atlantic Biologicals) and 1\% (v/v) penicillin and streptomycin. Cultures were maintained at $37^{\circ} \mathrm{C}$ in a humidified incubator containing $5 \%(\mathrm{v} / \mathrm{v}) \mathrm{CO}_{2}$.

U87 and MDA-MB-231 cells were plated in 96-well flat-bottom microplates at a density of 3000 cells per well in $100 \mu \mathrm{L}$ of complete culture medium. Cells were incubated for $24 \mathrm{~h}$ to ensure proper cell adherence and stability. On day 2, the cells were treated with $\mathrm{He} \mu \mathrm{CAP}$ for $0,5,10,30,60$, or 120 seconds. Cells were further incubated at $37^{\circ} \mathrm{C}$ for 24 and $48 \mathrm{~h}$. The viability of the glioblastoma and breast cancer cells was measured for each incubation time point with an MTT assay. $100 \mu \mathrm{L}$ of MTT solution (3-(4,5-dimethylthiazol-2-yl)-2,5-diphenyltetrazolium bromide) (Sigma-Aldrich) was added to each well, and plates were incubated for $3 \mathrm{~h}$. The MTT solution was discarded, and $100 \mu \mathrm{L}$ per well of MTT solvent $(0.4 \%(\mathrm{v} / \mathrm{v}) \mathrm{HCl}$ in anhydrous isopropanol) was

added to the wells. The absorbance of the purple solution was recorded at $570 \mathrm{~nm}$ with a Synergy H1 Hybrid Multi-Mode Microplate Reader.

\section{RESULTS AND DISC USSION}

The reactive species generated by the $\mu \mathrm{CAP}$ device with different tube lengths are detected by optical emission spectroscopy, as shown in Fig. 3. The identification of the 

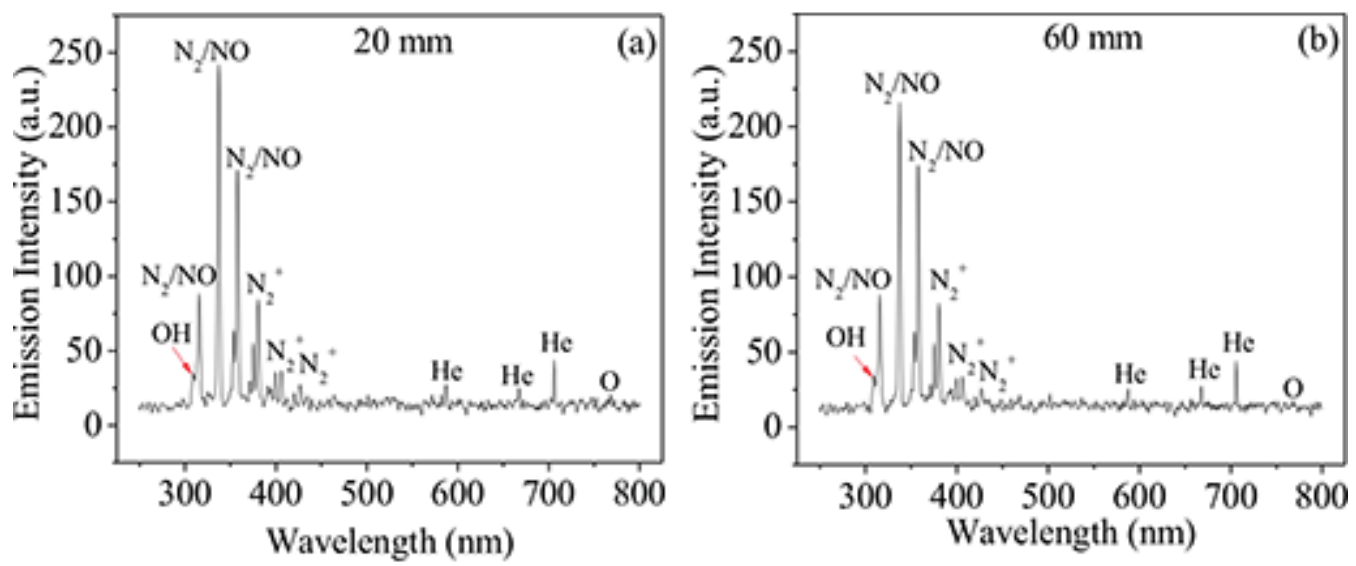

FIG. 3: Optical emission spectrum detected from the He $\mu \mathrm{CAP}$ with tubes of length $20 \mathrm{~mm}$ (a) and $60 \mathrm{~mm}$ (b) using UV-visible-NIR, with wavelengths of $250-850 \mathrm{~nm}$

emission line and bands was performed mainly according to reference. ${ }^{30}$ For devices with tubes that were $20 \mathrm{~mm}$ and $60 \mathrm{~mm}$ long, an $\mathrm{N}_{2}$ second-positive system $(315 \mathrm{~nm}$, $337 \mathrm{~nm}, 357 \mathrm{~nm}$, and $380 \mathrm{~nm}$ ) representing the photon emission intensity drops from the state $C^{3} \Pi u$ to $\beta^{3} \Pi g$ with different upper and lower vibration quantum numbers. There are very weak emission lines in the special range of 250 to $300 \mathrm{~nm}$, which are detected as NO lines. The helium bands were assigned between 500 and $750 \mathrm{~nm}$, as shown in Fig. $3 \mathrm{a}$ and $3 \mathrm{~b}$. We also observed a high-intensity $\mathrm{OH} / \mathrm{O}_{3}$ peak at $309 \mathrm{~nm}$ for devices with both $20 \mathrm{~mm}$ and $60 \mathrm{~mm}$ lengths. Atomic oxygen $(\mathrm{O}$, including the ground state and all the excited states of atomic oxygen) was observed at $777 \mathrm{~nm}$ in both devices, which was believed to have a significant effect on cells and therefore a broad biomedical application. Micro-sized plasma is a complicated mix that combines the comprehensive effect of different ions and reactive species. Because its delivery distance is longer, the $60 \mathrm{~mm}$ $\mu \mathrm{CAP}$ has fewer electrons and reactive species than the $20 \mathrm{~mm} \mu \mathrm{CAP}$.

The experimental Rayleigh microwave scattering (RMS) system was described previosuly. ${ }^{19}$ The detection of the scattered signal was accomplished using a homodyne scheme by means of an $I / Q$ mixer, providing in-phase $(I)$ and quadrature $(Q)$ outputs. For the entire range of scattered signals, the amplifiers and mixer were operated in linear mode. The total amplitude of the scattered microwave signal was determined by: $U=\sqrt{I^{2}+Q^{2}}$. We can calculate the total electron number in the plasma as $N_{e}=$ $U\left(w^{2}+v_{m}^{2}\right) /\left(2.82 \times 10^{-4} A v_{m}\right)$, where $w$ is the angular frequency, $v_{m}$ is the frequency of the electron-neutral collisions, and $A$ is the proportionality coefficient. ${ }^{31}$ The total electron number in the jet from $\mu$ CAPs with lengths of $20 \mathrm{~mm}$ and $60 \mathrm{~mm}$ is presented in Fig. $4 \mathrm{a}$ and $4 \mathrm{~b}$, and the total electron number for one discharge period is $4.60 \times 10^{12}$ and $4.04 \times 10^{12}$, respectively. A very small decrease of electron number has been detected in the $60 \mathrm{~mm} \mu \mathrm{CAP}$ compared to the $20 \mathrm{~mm} \mu \mathrm{CAP}$.

Volume 8, Issue 2, 2018 

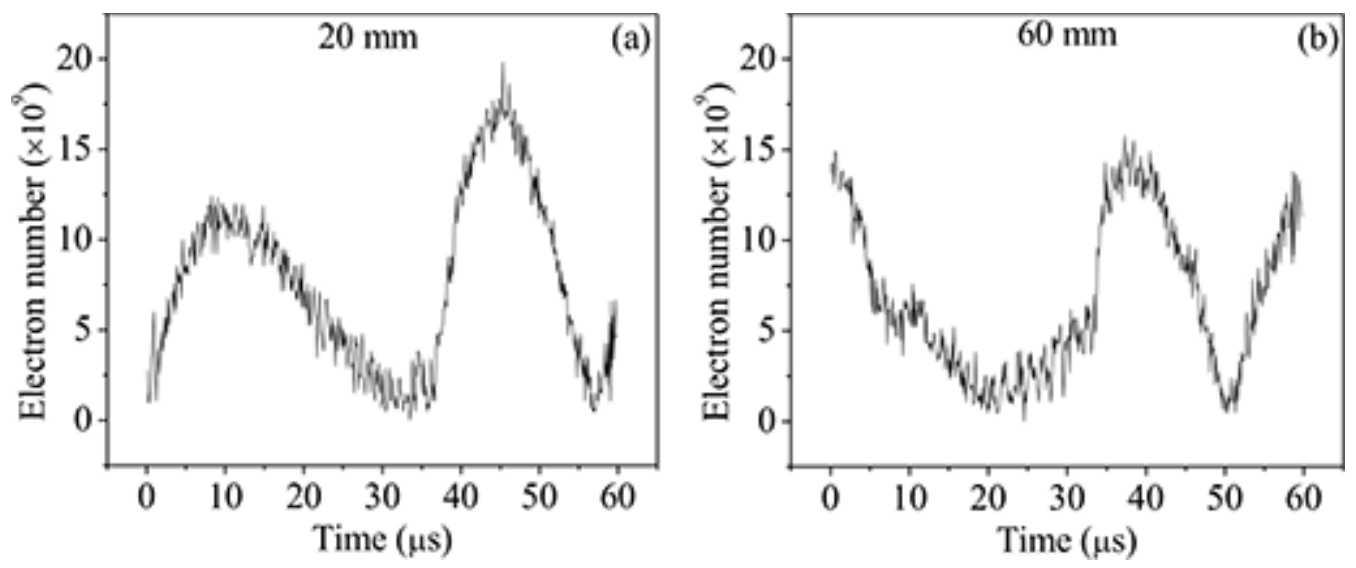

FIG. 4: The electron number of $20 \mathrm{~mm}$ (a) and $60 \mathrm{~mm}$ (b) lengths of $\mu \mathrm{CAP}$

XTT solution was used to determine the relative concentration of superoxide $\left(\mathrm{O}_{2}^{-}\right)$. Superoxide radical reduced soluble formazans of the tetrazolium dye XTT. ${ }^{32,33}$ Figure 5a and $5 \mathrm{~b}$ shows the relative superoxide concentration of $20 \mathrm{~mm}$ and $60 \mathrm{~mm} \mu$ CAP treatment of DMEM. Relative intensity increases with treatment, which corresponds to the relative concentration of superoxide increasing with treatment. Comparing the $20 \mathrm{~mm}$ with $60 \mathrm{~mm}$ lengths, the $20 \mathrm{~mm} \mu \mathrm{CAP}$ device produced a higher relative concentration of superoxide than the $60 \mathrm{~mm}$ device. Methylene blue (MB) was used to assess the relative concentration of hydroxyl radicals $(\bullet \mathrm{OH})$. MB reacts with $\bullet \mathrm{OH}$ aqueous solutions, leading to a visible color change. ${ }^{34}$ Figure $5 \mathrm{c}$ and $5 \mathrm{~d}$ shows that the relative $\mathrm{MB}$ concentration decreases with the treatment time of $\mu \mathrm{CAP}$, suggesting that more $\cdot \mathrm{OH}$ species are generated in DMEM $(20 \mathrm{~mm}>60 \mathrm{~mm})$. Overall, these findings demonstrate that there is an increase in the relative concentration of $\mathrm{O}_{2}^{-}$and $\bullet \mathrm{OH}$ as a function of $\mu \mathrm{CAP}$ treatment time.

DMEM treated with the $20 \mathrm{~mm}$ and $60 \mathrm{~mm} \mu \mathrm{CAP}$ devices induced changes in the concentration of $\mathrm{H}_{2} \mathrm{O}_{2}$ and $\mathrm{NO}_{2}{ }^{-}$as a function of the treatment time. These results are shown in Fig. 6, with concentrations produced by the $20 \mathrm{~mm}$ and $60 \mathrm{~mm}$ He $\mu$ CAP devices. In Fig. 6a, the $\mathrm{H}_{2} \mathrm{O}_{2}$ concentrations produced by the $20 \mathrm{~mm}$ He $\mu$ CAP device increased with treatment time up to $60 \mathrm{sec}$; but between 60 and $120 \mathrm{sec}$, the concentration decreased. The $\mathrm{H}_{2} \mathrm{O}_{2}$ concentration produced by $60 \mathrm{~mm} \mathrm{He} \mu \mathrm{CAP}$ increased with treatment time (see Fig. 6b). This result means that the $\mathrm{H}_{2} \mathrm{O}_{2}$ concentration reaches saturation earlier in the $20 \mathrm{~mm}$ length than with the $60 \mathrm{~mm}$ length $\mu \mathrm{CAP}$ device. In Fig. 5, we know that $\mathrm{He} \mu \mathrm{CAP}$ produces $\cdot \mathrm{OH}$ and $\mathrm{O}_{2}^{-}$in DMEM, which are the two most important species in plasma-activated media. In particular, $\bullet \mathrm{OH}$ reacting with - $\mathrm{OH}$ and $\mathrm{O}_{2}{ }^{-}$reacting with $2 \mathrm{H}^{+}$lead to $\mathrm{H}_{2} \mathrm{O}_{2}$ formation. ${ }^{35} \mathrm{NO}_{2}{ }^{-}$concentrations of both the $20 \mathrm{~mm}$ and $60 \mathrm{~mm}$ devices increase with treatment time (see Fig. 6c and 6d), and $\mathrm{NO}_{2}{ }^{-}$concentrations of the $20 \mathrm{~mm}$ device is much higher than that for the $60 \mathrm{~mm}$ device. Comparing $\mathrm{NO}_{2}^{-}$concentration with the $\mathrm{H}_{2} \mathrm{O}_{2}$ concentration under the same conditions, $\mathrm{NO}_{2}^{-}$concentration is much higher than $\mathrm{H}_{2} \mathrm{O}_{2}$ concentration. A possible hypothesis for this result is that DMEM comprises over 30 components such as in- 

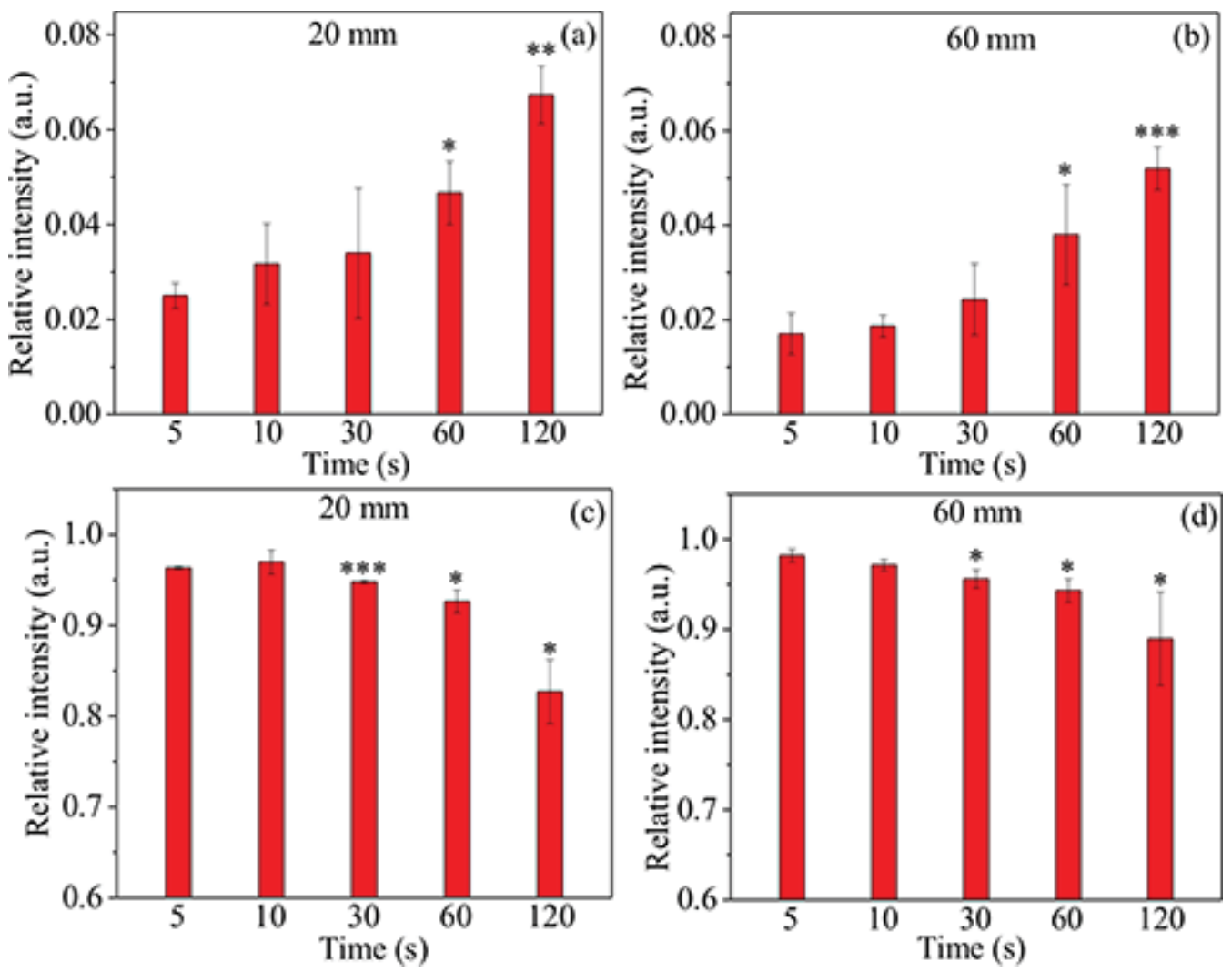

FIG. 5: Relative $\mathrm{O}_{2}{ }^{-}$and $\bullet \mathrm{OH}$ concentration of $20 \mathrm{~mm}$ and $60 \mathrm{~mm} \mu \mathrm{CAP}$-treated DMEM. For relative $\mathrm{O}_{2}^{-}$concentration: (a) $20 \mathrm{~mm}$ and (b) $60 \mathrm{~mm}$. For relative $\cdot \mathrm{OH}$ concentration: (c) $20 \mathrm{~mm}$ and (d) $60 \mathrm{~mm}$. Student's t-test was performed, and the statistical significance compared to $\mu \mathrm{CAP}$ $5 \mathrm{~s}$ treatment is indicated as $* \mathrm{p}<0.05, * * \mathrm{p}<0.01, * * * \mathrm{p}<0.001(\mathrm{n}=3)$.

organic salts, amino acids, and vitamins, and plasma might react with amino acids to form $\mathrm{NO}_{2}^{-}$.

Figure 7 shows the viability of the brain (glioblastoma U87) cancer cells after 24 and $48 \mathrm{~h}$ incubation with $\mu$ CAP during 5, 10, 30,60, and $120 \mathrm{sec}$ treatment with the $20 \mathrm{~mm}$ and $60 \mathrm{~mm}$ length $\mu \mathrm{CAP}$ devices, respectively. For the $20 \mathrm{~mm}$ length $\mu \mathrm{CAP}$ treatment, the cell viability of brain cancer cells was lower than that for the $60 \mathrm{~mm}$ length at each treatment duration (from 5 to $60 \mathrm{sec}$ ), and dropped with increasing treatment time. For both $20 \mathrm{~mm}$ and $60 \mathrm{~mm}$ devices, $120 \mathrm{sec}$ treatment has a similar effect on cell viability of U87 cancer cells. For $48 \mathrm{~h}$ incubation under $20 \mathrm{~mm} \mu \mathrm{CAP}$ treatment, 60 and $120 \mathrm{sec}$ duration had a similar effect on cell viability. Thus, our overall conclusion is that the 60 $\mathrm{mm}$ tube can still produce reactive species in deeper tumors.

Figure 8 shows the viability of the breast (MDA-MB-231) cancer cells after 24 and $48 \mathrm{~h}$ incubation with $\mu \mathrm{CAP}$ treatment with the $20 \mathrm{~mm}$ and $60 \mathrm{~mm}$ length $\mu \mathrm{CAP}$ devices

Volume 8, Issue 2, 2018 

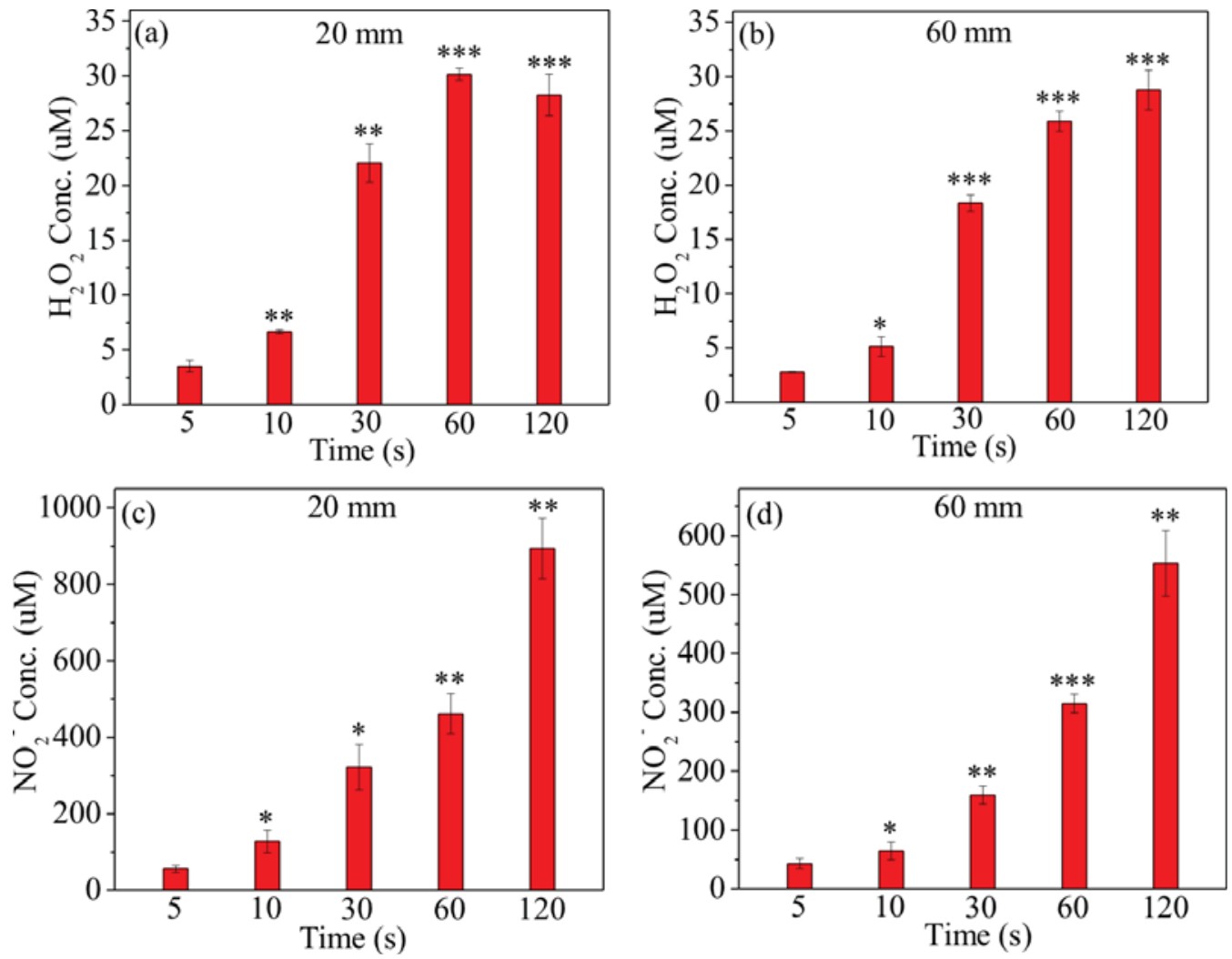

FIG. 6: $\mathrm{H}_{2} \mathrm{O}_{2}$ and $\mathrm{NO}_{2}{ }^{-}$concentration of $20 \mathrm{~mm}$ and $60 \mathrm{~mm} \mu$ CAP-treated DMEM. For $\mathrm{H}_{2} \mathrm{O}_{2}$ concentration: (a) $20 \mathrm{~mm}$ and (b) $60 \mathrm{~mm}$. For $\mathrm{NO}_{2}^{-}$concentration: (c) $20 \mathrm{~mm}$ and (d) $60 \mathrm{~mm}$. Student's t-test was performed, and the statistical significance compared to $\mu$ CAP $5 \mathrm{sec}$ treatment is indicated as $* \mathrm{p}<0.05,{ }^{* *} \mathrm{p}<0.01,{ }^{* * *} \mathrm{p}<0.001(\mathrm{n}=3)$.

during $5,10,30,60$, or $120 \mathrm{sec}$ duration. For both $20 \mathrm{~mm}$ and $60 \mathrm{~mm} \mu \mathrm{CAP}$ treatment, cell viability after 24 and $48 \mathrm{~h}$ incubation dropped with increasing treatment time. For $20 \mathrm{~mm} \mu \mathrm{CAP}$ treatment, the viability of breast cancer cells was lower than that of the $60 \mathrm{~mm}$ length at each treatment duration.

The direct plasma jet irradiation is limited to the skin. It can also be invoked as a supplemental therapy during surgery because it only causes cell death in the upper three to five cell layers. However, the current cannulas from which the plasma emanates are too large for intracranial applications. Thus, we developed micro-sized plasma devices with $20 \mathrm{~mm}$ and $60 \mathrm{~mm}$ length stainless steel tubes, both of which can effectively kill brain and breast cancer cells. This preliminary study offers significant potential for new treatment applications. Numerous studies reported plasma-induced apoptosis in cancer cells due to various plasma-generated reactive species. ${ }^{1,36,37}$ Plasma generates multiple ROS and RNS, including hydrogen peroxide $\left(\mathrm{H}_{2} \mathrm{O}_{2}\right)$, ozone $\left(\mathrm{O}_{3}\right)$, 

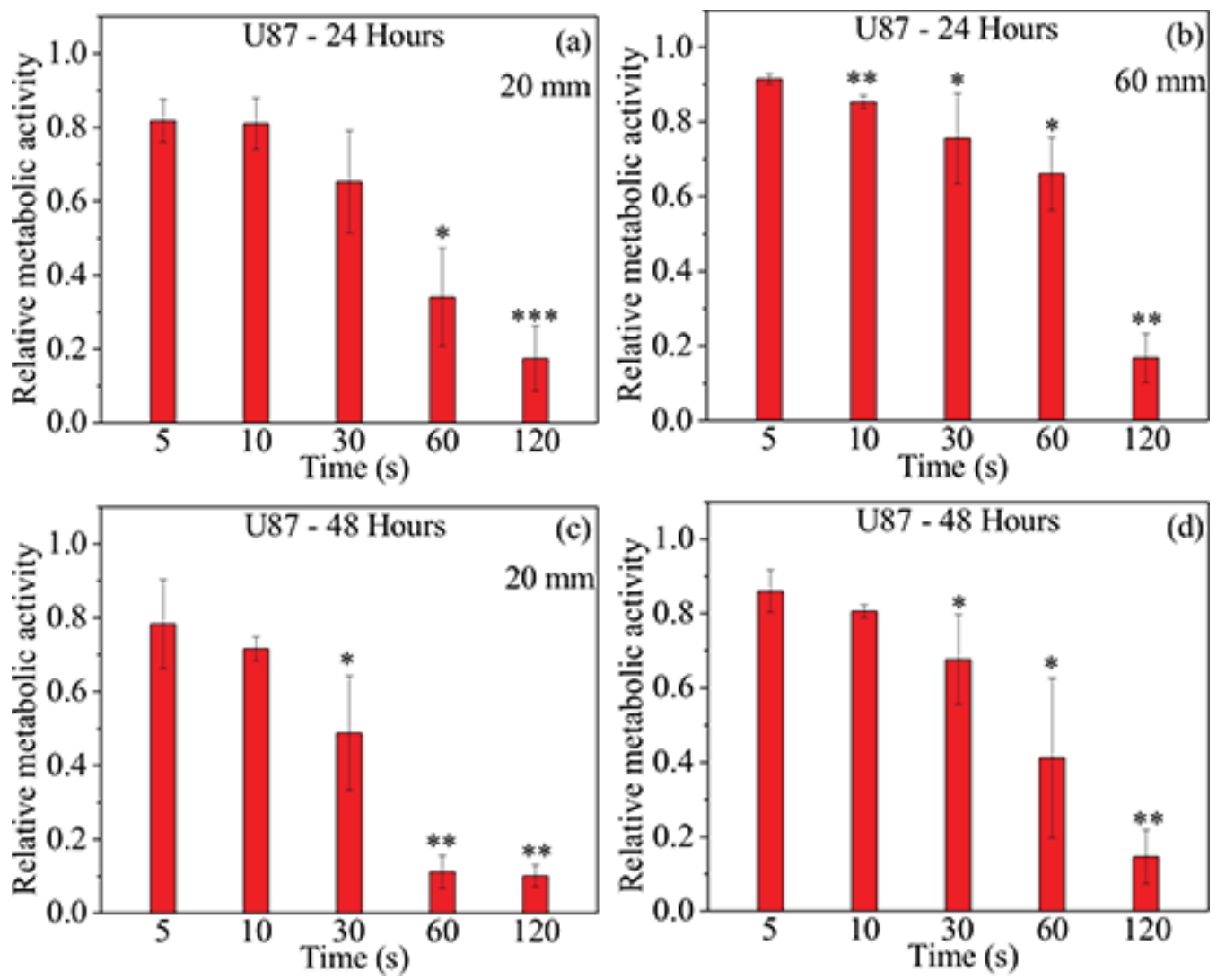

FIG. 7: Cell viability of U87 after 24 and $48 \mathrm{~h}$ incubation with $\mu$ CAP treatment with $20 \mathrm{~mm}$ and $60 \mathrm{~mm}$ length during 5, 10, 30, 60, and $120 \mathrm{sec}$ treatments. Cell viability of U87 treated by 20 $\mathrm{mm} \mathrm{He} \mu \mathrm{CAP}$ at (a) $24 \mathrm{~h}$ incubation and (c) $48 \mathrm{~h}$ incubation. Cell viability of U87 treated by 60 $\mathrm{mm} \mathrm{He} \mu \mathrm{CAP}$ at (b) $24 \mathrm{~h}$ incubation and (d) $48 \mathrm{~h}$ incubation. The ratios of surviving cells for each cell line were normalized relative to controls (DMEM). Student's t-test was performed, and the statistical significance compared to cells present in DMEM is indicated as ${ }^{*} \mathrm{p}<0.05,{ }^{* *} \mathrm{p}<$ $0.01, * * * \mathrm{p}<0.005(\mathrm{n}=3)$.

hydroxyl radical $(\cdot \mathrm{OH})$, atomic oxygen $(\mathrm{O})$, superoxide $\left(\mathrm{O}_{2}^{-}\right)$, nitric oxide $(\mathrm{NO})$ and peroxynitrite anion $\left(\mathrm{ONOO}^{-}\right)$, singlet delta oxygen $\left(\mathrm{O}_{2}\left({ }^{1} \Delta_{\mathrm{g}}\right)\right.$ ), and nitrite $\left(\mathrm{NO}_{2}^{-}\right) \cdot{ }^{37,38}$ All of these are shown in Fig. 3. In these experiments, we have specifically measured relative concentrations of $\mathrm{O}_{2}^{-}$and $\bullet \mathrm{OH}$ (short-lived species, see Fig. 5) and the concentration of $\mathrm{H}_{2} \mathrm{O}_{2}$ and $\mathrm{NO}_{2}^{-}$(long-lived species, see Fig. 6). The relative concentration of $\mathrm{O}_{2}{ }^{-}$treated by $\mu \mathrm{CAP}$ devices with $20 \mathrm{~mm}$ and $60 \mathrm{~mm}$ lengths increases with treatment time (see Fig. 5a and 5b). $\mathrm{O}_{2}^{-}$can activate mitochondrial-mediated apoptosis by changing the mitochondrial membrane potential. It simultaneously upregulates pro-apoptotic genes and downregulates anti-apoptotic genes for activation of caspases resulting in cell death. ${ }^{39}$ Figure $5 \mathrm{c}$ and $5 \mathrm{~d}$ shows the relative concentration of $\bullet \mathrm{OH}$ in DMEM treated by $\mu \mathrm{CAP}$ with $20 \mathrm{~mm}$ and $60 \mathrm{~mm}$ lengths also increases with treatment time.

Volume 8, Issue 2, 2018 

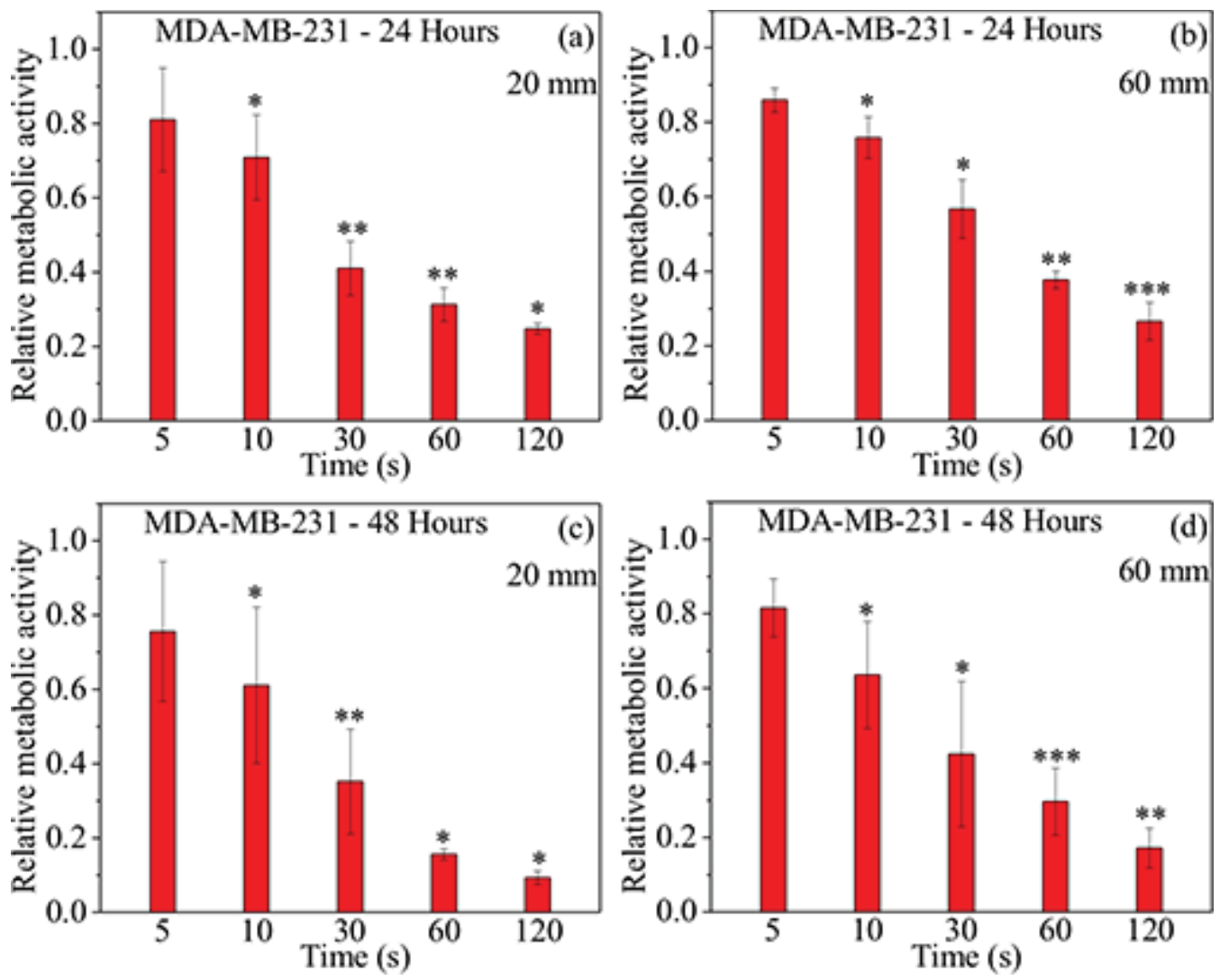

FIG. 8: Cell viability of MDA-MB-231 after 24 and $48 \mathrm{~h}$ incubation with $\mu$ CAP treatment with $20 \mathrm{~mm}$ and $60 \mathrm{~mm}$ length during 5, 10, 30, 60, and $120 \mathrm{sec}$ treatment. Cell viability of MDAMB-231 treated by $20 \mathrm{~mm} \mathrm{He} \mu \mathrm{CAP}$ at (a) $24 \mathrm{~h}$ incubation and (c) $48 \mathrm{~h}$ incubation. Cell viability of MDA-MB-231 treated by $60 \mathrm{~mm}$ He $\mu \mathrm{CAP}$ at (b) 24-h incubation and (d) 48-h incubation. The ratios of surviving cells for each cell line were calculated relative to controls (DMEM). Student's t-test was performed, and the statistical significance compared to cells present in DMEM is indicated as $* \mathrm{p}<0.05, * * \mathrm{p}<0.01, * * \mathrm{p}<0.005(\mathrm{n}=3)$.

- $\mathrm{OH}$ derived amino acid peroxides can contribute to cell injury because $\bullet \mathrm{OH}$ itself and protein (amino acid) peroxides react with DNA, thereby inducing various forms of damage.$^{40}$ Compared with cell viability of both cancer lines, the trend of cell death can be partly attributed to the increase of $\mathrm{O}_{2}{ }^{-}$and $\bullet \mathrm{OH}$ concentrations with treatment time. On the other hand, the $20 \mathrm{~mm} \mu \mathrm{CAP}$ device shows higher relative concentrations of $\mathrm{O}_{2}{ }^{-}$and $\bullet \mathrm{OH}$, such that the $20 \mathrm{~mm} \mu \mathrm{CAP}$ device is more effective in killing both cancer cell lines than the $60 \mathrm{~mm} \mu \mathrm{CAP}$ device. Figure 6 shows $\mathrm{H}_{2} \mathrm{O}_{2}$ and $\mathrm{NO}_{2}{ }^{-}$concentrations of the DMEM treated with the $20 \mathrm{~mm}$ and $60 \mathrm{~mm} \mu \mathrm{CAP}$ devices. $\mathrm{H}_{2} \mathrm{O}_{2}$ can induce cell death by apoptosis and necrosis, whereas $\mathrm{NO}_{2}{ }^{-}$is known to induce cell death via DNA damage. ${ }^{36,41}$ Thus, the synergism of $\mathrm{H}_{2} \mathrm{O}_{2}$ and $\mathrm{NO}_{2}{ }^{-}$might be an important factor in the efficiency of killing cancer cells. 
Several methods, such as chemotherapy, surgery, and radiotherapy, are now being used for cancer treatment. ${ }^{42-44}$ The conventional methods have some disadvantages, such as longer treatment times, high cost, and adverse effects. However, plasma treatment may overcome the disadvantages of traditional treatments. Currently, plasma can be directly applied to skin cancers, but they are not useful for more systemic cancer treatment. However, we developed novel $\mu$ CAP devices with $20 \mathrm{~mm}$ and $60 \mathrm{~mm}$ lengths, which can be considered as a local treatment tool. Plasma does not have the systemic therapeutic effects seen with chemical therapies. In addition, these devices do not have the limitations normally associated with plasmas. Overall, the previously discussed results indicate that $\mu \mathrm{CAP}$ devices with either a $20 \mathrm{~mm}$ or $60 \mathrm{~mm}$ length might be useful and should be considered in a clinical medical application.

\section{CONCLUSIONS}

In this work, we showed that the newly developed micro-sized cold atmospheric plasma $(\mu \mathrm{CAP}$ ) device with $20 \mathrm{~mm}$ and $60 \mathrm{~mm}$ length stainless steel tubes induce the formation of reactive species and radicals in culture medium. There is an increase in the concentration of $\mathrm{O}_{2}^{-}, \bullet \mathrm{OH}, \mathrm{H}_{2} \mathrm{O}_{2}$, and $\mathrm{NO}_{2}^{-}$as a function of $\mu \mathrm{CAP}$ treatment time, which matches the trend of cell viability of two cancer cells with $\mu$ CAP treatment time. A synergistic effect of short- and long-lived species present in the plasma treating DMEM is suspected to play a key role in cell death. Both the 20 and $60 \mathrm{~mm}$ length devices have significant effects on both U87 and MDA-MB-231 cancer cell viability, allowing access to both superficial and deeper tumors. The results of this study suggest a possibility for clinical applications of this $\mu \mathrm{CAP}$ device on brain and breast tumors. Future work will focus on the use of $\mu \mathrm{CAP}$ devices inside the patient's body.

\section{ACKNOWHGGMENT}

This work was supported by the US Medical Innovation (USMI) through joint GWU/ USMI plasma medicine program.

\section{REFERENCES}

1. Keidar M. Plasma for cancer treatment. Plasma Sources Sci Technol. 2015;24(3):033001.

2. Keidar M, Walk R, Shashurin A, Srinivasan P, Sandler A, Dasgupta S, Ravi R, Guerrero-Preston R, Trink B. Cold plasma selectivity and the possibility of a paradigm shift in cancer therapy. Br J Cancer. 2011;105(9):1295-301.

3. Dezest M, Chavatte L, Bourdens M, Quinton D, Camus M, Garrigues L, Descargues P, Arbault S, Burlet-Schiltz O, Casteilla L, Clément F, Planat V, Bulteau A. Mechanistic insights into the impact of cold atmospheric pressure plasma on human epithelial cell lines. Sci Rep. 2017;7:41163.

4. Cheng X, Sherman J, Murphy W, Ratovitski E, Canady J, Keidar M. The effect of tuning cold plasma composition on glioblastoma cell viability. PLoS One. 2014;9(5):e98652.

Volume 8, Issue 2, 2018 
5. Attri P, Sarinont T, Kim M, Amano T, Koga K, Cho AE, Choi EH, Shiratani M. Influence of ionic liquid and ionic salt on protein against the reactive species generated using dielectric barrier discharge plasma. Sci Rep. 2015;5:17781.

6. Lunov O, Zablotskii V, Churpita O, Chánová E, Syková E, Dejneka A, Kubinová Š. Cell death induced by ozone and various non-thermal plasmas: therapeutic perspectives and limitations. Sci Rep. 2014;4:7129.

7. Fridman G, Friedman G, Gutsol A, Shekhter AB, Vasilets VN, Fridman A. Applied plasma medicine. Plasma Process Polym. 2008;5(6):503-33.

8. Dikalov SI, Harrison DG. Methods for detection of mitochondrial and cellular reactive oxygen species. Antioxid Redox Signal. 2014;20(2):372-82.

9. Kalghatgi S, Friedman G, Fridman A, Clyne AM. Endothelial cell proliferation is enhanced by low dose non-thermal plasma through fibroblast growth factor-2 release. Ann Biomed Eng. 2010; 38(3):748-57.

10. Gjika E, Pal-Ghosh S, Tang A, Kirschner M, Tadvalkar G, Canady J, Stepp MA, Keidar M. Adaptation of operational parameters of cold atmospheric plasma for in vitro treatment of cancer cells. ACS Appl. Mater. Interfaces, 2018;10 (11):9269-9279.

11. Vandamme M, Robert E, Pesnel S, Barbosa E, Dozias S, Sobilo J, Lerondel S, Pape AL, Pouvesle JM. Antitumor effect of plasma treatment on U87 glioma xenografts: preliminary results. Plasma Process Polym. 2010;7(3-4):264-73.

12. Chen Z, Lin L, Cheng X, Gjika E, Keidar M. Treatment of gastric cancer cells with nonthermal atmospheric plasma generated in water. Biointerphases. 2016;11(3):031010.

13. Ishaq M, Evans MM, Ostrikov KK. Effect of atmospheric gas plasmas on cancer cell signaling. Int J Cancer. 2014;134(7):1517-28.

14. Hirst A, Simms M, Mann V, Maitland N, O'Connell D, Frame F. Low-temperature plasma treatment induces DNA damage leading to necrotic cell death in primary prostate epithelial cells. Br J Cancer. 2015;112(9):1536-45.

15. Utsumi F, Kajiyama H, Nakamura K, Tanaka H, Mizuno M, Ishikawa K, Kondo H, Kano H, Hori M, Kikkawa F. Effect of indirect nonequilibrium atmospheric pressure plasma on anti-proliferative activity against chronic chemo-resistant ovarian cancer cells in vitro and in vivo. PLoS One. 2013;8(12):e81576.

16. Kim JY, Ballato J, Foy P, Hawkins T, Wei Y, Li J, Kim SO. Apoptosis of lung carcinoma cells induced by a flexible optical fiber-based cold microplasma. Biosens Bioelectron. 2011;28(1):333-8

17. Zhang X, Li M, Zhou R, Feng K, Yang S. Ablation of liver cancer cells in vitro by a plasma needle. Appl Phys Lett. 2008;93(2):021502.

18. Volotskova O, Hawley TS, Stepp MA, Keidar M. Targeting the cancer cell cycle by cold atmospheric plasma. Sci Rep. 2012;2:636.

19. Chen Z, Cheng X, Lin L, Keidar M. Cold atmospheric plasma discharged in water and its potential use in cancer therapy. J Phys D Appl Phys. 2016;50(1):015208.

20. Arndt S, Wacker E, Li YF, Shimizu T, Thomas HM, Morfill GE, Karrer S, Zimmermann JL, Bosserhoff AK. Cold atmospheric plasma, a new strategy to induce senescence in melanoma cells. Exp Dermatol. 2013;22(4):284-9.

21. Georgescu N, Lupu AR. Tumoral and normal cells treatment with high-voltage pulsed cold atmospheric plasma jets. IEEE Trans Plasma Sci. 2010;38(8):1949-55.

22. Brullé L, Vandamme M, Riès D, Martel E, Robert E, Lerondel S, Trichet V, Richard S, Pouvesle JM, Pape AL. Effects of a non thermal plasma treatment alone or in combination with gemcitabine in a MIA PaCa2-luc orthotopic pancreatic carcinoma model. PLoS One. 2012;7(12):e52653.

23. Ahn HJ, Kim KI, Kim G, Moon E, Yang SS, Lee J-S. Atmospheric-pressure plasma jet induces apoptosis involving mitochondria via generation of free radicals. PLoS One. 2011;6(11):e28154.

24. Guerrero-Preston R, Ogawa T, Uemura M, Shumulinsky G, Valle BL, Pirini F, Ravi R, Sidransky D, Keidar M, Trink B. Cold atmospheric plasma treatment selectively targets head and neck squamous cell carcinoma cells. Int J Mol Med. 2014;34(4):941-6. 
25. Chen Z, Lin L, Cheng X, Gjika E, Keidar M. Effects of cold atmospheric plasma generated in deionized water in cell cancer therapy. Plasma Process Polym. 2016;13(12):1151-6.

26. Chen Z, Lin L, Gjika E, Cheng X, Canady J, Keidar M. Selective treatment of pancreatic cancer cells by plasma-activated saline solutions. IEEE Trans Radiat Plasma Med Sci. 2017;2(2):116-20.

27. Chen Z, Zhang S, Levchenko I, Beilis II, Keidar M. In vitro demonstration of cancer inhibiting properties from stratified self-organized plasma-liquid interface. Sci Rep. 2017;7(1):12163.

28. Scholtz V, Julák J, Kř́iha V. The microbicidal effect of low-temperature plasma generated by corona discharge: comparison of various microorganisms on an agar surface or in aqueous suspension. Plasma Process Polym. 2010;7(3-4):237-43.

29. Mirpour S, Piroozmand S, Soleimani N, Faharani NJ, Ghomi H, Eskandari HF, Sharifi AM, Mirpour S, Eftekhari M, Nikkhah M. Utilizing the micron sized non-thermal atmospheric pressure plasma inside the animal body for the tumor treatment application. Sci Rep. 2016;6:29048.

30. Pearse RWB, Gaydon AG. Identification of molecular spectra. London: Chapman and Hall; 1976.

31. Lin L, Keidar M. Cold atmospheric plasma jet in an axial DC electric field. Phys Plasmas. 2016;23(8):083529.

32. Sutherland MW, Learmonth BA. The tetrazolium dyes MTS and XTT provide new quantitative assays for superoxide and superoxide dismutase. Free Radic Res. 1997;27(3):283-9.

33. Bartosz G. Use of spectroscopic probes for detection of reactive oxygen species. Clin Chim Acta. 2006;368(1):53-76.

34. Satoh AY, Trosko JE, Masten SJ. Methylene blue dye test for rapid qualitative detection of hydroxyl radicals formed in a Fenton's reaction aqueous solution. Environ Sci Technol. 2007;41(8):2881-7.

35. Locke BR, Shih K-Y. Review of the methods to form hydrogen peroxide in electrical discharge plasma with liquid water. Plasma Sources Sci Technol. 2011;20(3):034006.

36. Chen Z, Simonyan H, Cheng X, Gjika E, Lin L, Canady J, Sherman JH, Young C, Keidar M. A novel micro cold atmospheric plasma device for glioblastoma both in vitro and in vivo. Cancers (Basel). 2017;9(6):E61.

37. Graves DB. The emerging role of reactive oxygen and nitrogen species in redox biology and some implications for plasma applications to medicine and biology. J Phys D Appl Phys. 2012;45(26):263001.

38. Laroussi M, Leipold F. Evaluation of the roles of reactive species, heat, and UV radiation in the inactivation of bacterial cells by air plasmas at atmospheric pressure. Int J Mass Spectrom. 2004;233(1):81-6.

39. Riedl SJ, Shi Y. Molecular mechanisms of caspase regulation during apoptosis. Nat Rev Mol Cell Biol. 2004;5(11):897-907.

40. Adachi T, Tanaka H, Nonomura S, Hara H, Kondo S, Hori M. Plasma-activated medium induces A549 cell injury via a spiral apoptotic cascade involving the mitochondrial-nuclear network. Free Radic Biol Med. 2015;79:28-44.

41. Boehm D, Heslin C, Cullen PJ, Bourke P. Cytotoxic and mutagenic potential of solutions exposed to cold atmospheric plasma. Sci Rep. 2016;6:21464.

42. Arap W, Pasqualini R, Ruoslahti E. Cancer treatment by targeted drug delivery to tumor vasculature in a mouse model. Science. 1998;279(5349):377-80.

43. Morris T, Steven Greer H, White P. Psychological and social adjustment to mastectomy: a two-year follow-up study. Cancer. 1977;40(5):2381-7.

44. Delaney G, Jacob S, Featherstone C, Barton M. The role of radiotherapy in cancer treatment. Cancer. 2005;104(6):1129-37.

Volume 8, Issue 2, 2018 
